Volume 3 Issue 2, September 2019: pp. 212-235. Copyright @) 2019 HOLREV. Faculty of Law, Halu Oleo University, Kendari, Southeast Sulawesi, Indonesia. ISSN: 2548-1762 | e-ISSN: 2548-1754. Open Access at: http://ojs. uho. ac. id/index. php/holrev/

Halu Oleo Law Review is licensed under a Creative Commons Attribution 4. 0 International License, which permits unrestricted use, distribution, and reproduction in any medium, provided the original work is properly cited.

\title{
Hak Reproduksi Perempuan dan Hukum Pidana
}

\author{
Women's Reproductive Rights and Criminal Law
}

\author{
Kuswardani \\ Fakultas Hukum, Universitas Muhammadiyah Surakarta \\ E-mail: kus283@ums.ac.id \\ Handrawan \\ Dosen Pascasarjana, Universitas Halu Oleo, Kendari, Sulawesi Tenggara \\ E-mail: handrawansaranani84@gmail.com \\ Widhia Kusuma Wardhani \\ Mahasiswa Fakultas Hukum Universitas Gajah Mada \\ E-mail: widhiakusumawardani@gmail.com
}

\begin{abstract}
Women's human rights are different from men's human rights, the difference being in reproductive rights. Criminal law is a tool that provides protection against violation of human rights include violation of reproductive right of women. This paper studies regulation of criminal law on offence or crime against reproductive right of women. This study uses normative approach, discussion focus is National Criminal Law (Penal Code and criminal law beyond Penal Code). Result study shows that, the regulation of offence or crime against reproductive rights of women are Code of Penal on morality delict, Law No. 23 of 2002 on Child Protection Law with several amendments, Law No. 23 of 2004 on the Elimination of Domestic Violence, and Law No. 21 of 2007 on the Eradication of Crime in human Trafficking. There are several things that must be committed by the state, firstly reformulation on the regulation of adultery and rape. Secondly the new formulation about sexual harassment is clearer and more explicit.
\end{abstract}

Keyword: Right of women's reproductive; criminal law; human rights

Abstrak: Hak asasi manusia perempuan berbeda dengan hak asasi manusia lakilaki, perbedaan ada pada hak reproduksinya. Hukum pidana sebagai suatu alatyang memberikan perlindungan terhadap pelanggaran hak asasi itu termasuk pelanggaran hak reproduksi perempuan. Makalah ini mengkaji tentang pengaturan hukum pidana terhadap pelanggaran atau kejahatan terhadap hak reproduksi perempuan. Kajian ini menggunakan pendekatan normatif, fokus pembahasan adalah pengaturan undang-undang pidana nasional (KUHP dan UU pidana di luar KUHP) terhadap kejahatan hak reproduksi perempuan. Hasil kajian menunjukkan bahwa pengaturan kejahatan terhadap hak reproduksi perempuan ada di KUHP 
khususnya tentang kejahatan terhadap kesusilaan. UU No. 23/2002 tentang Perlindungan Anak dengan beberapa perubahannya, UU No. 23/2004 tentang Penghapusan Kekerasan Dalam Rumah Tangga, UU No. 21/2007 tentang Pemberantasan Tindak Pidana Perdagangan Orang. Ada beberapa hal yang harus dilakukan oleh negara pertama, reformulasi tentang pengaturan zina, dan/atau perkosaan. Kedua, perumusan formulasi baru tentang pelecehan seksual agar jelas dan tegas.

Kata kunci: Hak reproduksi perempuan; hukum pidana; hak asasi manusia

\section{PENDAHULUAN}

Perempuan menurut pandangan masyarakat sebagai makhluk yang memiliki keunikan, yang berbeda dengan makhluk laki-laki. Keunikan perempuan ini, karena hak reproduksi yang dimilikinya berbeda dengan laki-laki (mengandung, menyusui dan menstruasi). Hak yang demikian ini menurut sejarah gerakan feminis pernah menjadi perdebatan panjang, sehingga ada sekelompok feminis yang berpendapat bahwa hak reproduksi (hamil dan menyusui) perempuan yang melahirkan tanggung jawab reproduksi ini merupakan faktor yang membatasi pengembangan diri perempuan. Atau dengan kata lain perempuan tidak bisa sama dengan laki-laki, karena adanya hak tersebut, untuk itu perlu ada sarana lain untuk menggantikannya. Aliran demikian ini adalah aliran feminis radikal. ${ }^{1}$

Hak demikian ini seharusnya tidak menjadi kendala bagi perempuan untuk mengembangkan diri, dan tidak menjadi faktor untuk meminggirkan perempuan. Hak ini merupakan hak kodrati yang diberikan oleh Sang Pencipta, yang membedakan perempuan dengan laki-laki. Ini sebagai hak kodrati berarti merupakan hak asasi manusia perempuan, sehingga tidak bisa dirampas atau dimatikan oleh siapa pun termasuk oleh negara atau pemerintah. Penganut feminis post modern berpandangan bahwa perempuan adalah "liyan", namun keliyanan perempuan itu harus dimanfaatkan agar perempuan menjadi manusia yang utuh, selain itu berpandangan pula bahwa untuk menafsirkan tentang keliyanan perempuan itu harus ditransendenkan. ${ }^{2}$ Kata "ditransendenkan" asal kata "transenden" menurut Kamus Besar Bahasa Indonesia artinya di luar kesanggupan manusia, atau luar biasa atau utama. Dalam filsafat kata transenden, artinya melebihi maksudnya melebihi akal manusia, sehingga kata "transendence" selalu dikaitkan dengan

1 Rosemarie Putnam Thong. Pengantar Paling Komprehensif kepada Arus Utama Pemikiran Feminis. Yogyakarta: Jalasutra, 2004, hlm. 73.

2 Ibid, hlm. 286. 
Tuhan sebagai Sang Pencipta, yang tidak bisa ditangkap dengan akal manusia. ${ }^{3}$ Jadi kata "ditransendenkan" maksudnya bahwa dalam memandang perempuan khususnya dalam hal hak reproduksinya, tidak bisa dilepaskan dari nilai-nilai ketuhanan, yang ini di Indonesia menjiwai kehidupan dalam bermasyarakat, berbangsa dan bernegara. Selanjutnya, pembicaraan tentang hukum pidana sangat luas, sehingga akan muncul sebuah pertanyaan hukum pidana, yang mana yang dimaksud? Hukum pidana sebagai sebuah sistem itu meliputi pertama, hukum pidana substantif atau hukum pidana materiil atau yang sering disebut dengan hukum pidana saja. Kedua, hukum pidana formil atau hukum acara pidana, dan ketiga adalah hukum pelaksanaan pidana atau hukum pidana penintensier. ${ }^{4}$ Oleh karena itu, pengkajian dalam makalah ini hanya akan membatasi pada lingkup hukum pidana substantif.

Hukum pidana substantif/atau hukum pidana materiil, yang selanjutnya dalam makalah ini disebut dengan istilah hukum pidana saja, mempunyai tujuan dan fungsi. Tujuan hukum pidana adalah (1) untuk melindungi kepentingan individu dari kesewenang-wenangan penguasa; (2) melindungi masyarakat dari kejahatan. Fungsi hukum pidana meliputi fungsi umum dan fungsi khusus, fungsi umum adalah mengatur hidup kemasyarakatan atau menyelenggarakan tata tertib dalam masyarakat, sedangkan fungsi khususnya adalah melindungi kepentingan hukum terhadap perbuatan yang hendak memperkosanya dengan sanksi berupa pidana. ${ }^{5} \mathrm{Jadi}$, dengan kata lain bahwa tujuan dan fungsi hukum pidana adalah melindungi kepentingan individu, kepentingan masyarakat dan kepentingan negara.

Selanjutnya, ruang lingkup hukum pidana meliputi perbuatan pidana atau tindak pidana, pertanggungjawaban pidana dan sanksi pidana. Perbuatan pidana atau sering disebut sebagai kejahatan secara umum diberikan pengertian sebagai perbuatan yang memenuhi rumusan undang-undang, bersifat melawan hukum dan dapat dipidana. Konsep perbuatan pidana/kejahatan yang demikian itu dikaitkan dengan tujuan dan fungsi hukum pidana, maka perbuatan yang dirumuskan dalam undang-undang pidana adalah perbuatan yang melanggar hak-hak individu termasuk di sini adalah hak

3 Tom Jacob SJ. Faham Allah Dalam Filsafat Agama-Agama dan Teologi. Yogyakarta: Kanisus, 2002, hlm. 7778.

4 Barda Nawawi Arief. Perkembangan Sistem Pemidanaan di Indonesia. Semarang: Program Pascasarjana UNDIP, 2015, hlm. 2-4.

5 Eddy O Harriej. Prinsip-prinsip Hukum Pidana, Yogyakarta: Cahya Atma Pustaka, 2016, hlm. 28-31. Kepentingan menurut Hans Kelsen adalah sama dengan hak. Lihat Hans Kelsen, Teori Umum tentang Hukum dan Negara, Penerjemah Raisul Muttaqien, Bandung: Nusa Media, 2011, hlm. 116. 
reproduksi perempuan. Perbuatan yang melanggar atau menyerang hak reproduksi perempuan lazim di masyarakat disebut dengan kekerasan seksual. Ini karena hak reproduksi berkaitan dengan masalah seksual, yang sebenarnya hak reproduksi lebih luas daripada hak seksual. 6

Kekerasan seksual ini merupakan kejahatan yang sangat menakutkan perempuan, karena dampak dari kejahatan ini bisa dampak psikologis (seperti malu, trauma, gangguan stres yang bisa melakukan perbuatan yang membahayakan seperti bunuh diri), dampak kesehatan (penularan penyakit), bahkan perempuan yang mengalami kekerasan seksual (pelecehan seksual) mengalami kesehatan mental dan fisik lebih buruk, (seperti mencoba bunuh diri, mengancam) daripada perempuan yang mengalami kekerasan fisik, ${ }^{7}$ Fenomena yang terjadi bahwa kekerasan seksual tidak hanya terjadi di ruang publik, melainkan juga terjadi ruang privat atau personal. Kekerasan seksual di ruang publik maksudnya bahwa kekerasan seksual yang dilakukan oleh orang yang tidak dikenal, sedangkan kekerasan seksual di ranah personal, yaitu kekerasan seksual yang dilakukan orang terdekat seperti ayah kandung, tiri, tetangga, pacar atau saudara. Angka kekerasan seksual yang berhasil dicatat oleh KOMNAS Perempuan dalam dua tahun terakhir masih cukup tinggi, sebagaimana di bawah ini: ${ }^{8}$

Tabel. 1 Angka kekerasan seksual yang tercatat tahun 2017 dan 2018

\begin{tabular}{cccc}
\hline No. & Tahun & Ranah & Jumlah \\
\hline 1 & 2017 & Personal/Komunitas & $2979 / 2670$ \\
2 & 2018 & Personal/Komunitas & $2998 / 2521$ \\
\hline
\end{tabular}

Sumber: CATAHU KOMNAS Perempuan Tahun 2018 dan 2019.

Berdasarkan data di atas kekerasan seksual yang terjadi di ranah komunitas turun, namun perlu dipahami bahwa kejahatan itu ibarat fenomena gunung es, maksudnya bahwa yang tampak di permukaan hanya yang dilaporkan, sedangkan di luar masih banyak kekerasan seksual yang tidak dilaporkan, sehingga tidak bisa dicatat. Namun jumlah itu merupakan suatu hal yang memprihatinkan terutama kekerasan yang terjadi di ranah personal. Karena pelaku adalah orang dekat (ayah, saudara, pacar atau tetangga)

6 IPPF Organisation. Hak-Hak Seksual: Deklarasi IPPF. International Planned Parenthood Federation, 2006, https://www.ippf.org/sites/default/files/ippf_sexual_rights_declaration_bahasa.pdf, diakses pada tanggal 19 September 2019.

7 Lauren R. Taylor, Nicole Gaskin-Laniyan. "Sexual Assault in Abusive Relationships". NIJ Journal, Issue No. 256, 2007, hlm. 12-14.

8 Komisi Nasional Anti Kekerasan terhadap Perempuan, CATAHU: Catatan Tahunan 2018 dan 2019, https://www.komnasperempuan.go.id/file/pdf_file/2018/SIARAN\%20PERS\%202018/Lembar\%20Fak ta\%20Catahu\%207\%20Maret\%202018.pdf (2018), https://www.komnasperempuan.go.id/file/Catatan \%20Tahunan\%20Kekerasan\%20Terhadap\%20Perempuan\%202019.pdf (2019), diakses pada tanggal 17 Juli 2019. 
yang seharusnya memberikan perlindungan kepada perempuan itu, namun sebaliknya merusaknya.

Hukum pidana yang memiliki fungsi dan tujuan sebagaimana di atas harus bisa memberikan perlindungan pula terhadap hak reproduksi perempuan dengan merumuskan perbuatan-perbuatan yang melanggar hak reproduksi perempuan sebagai suatu kejahatan, dan dijatuhi sanksi pidana. Oleh karena itu tujuan dari makalah ini adalah untuk mendeskripsikan hukum pidana dalam memberikan perlindungan kepada hak reproduksi perempuan dalam rumusan pengaturannya, sehingga yang menjadi permasalahan adalah bagaimana pengaturan perbuatan pelanggaran hak reproduksi perempuan sebagai suatu kejahatan yang dapat dihukum dalam hukum pidana?

\section{METODE PENELITIAN}

Makalah ini merupakan penelitian hukum normatif, ${ }^{9}$ karena fokus kajian pada pengaturan atau formulasi hukum pidana dalam memberikan perlindungan kepada perempuan, agar tidak menjadi korban pelanggaran terhadap hak reproduksinya. Oleh karena itu data penelitian ini adalah dokumen hukum berupa peraturan-peraturan hukum pidana, yaitu KUHP dan undang-undang pidana di luar KUHP yang berkelindan dengan hak reproduksi perempuan. Namun juga tidak menutup kemungkinan penelitian ini juga menggunakan dokumen hukum di luar itu, yaitu KUHP Malaysia, KUHP India dan KUHP Belanda sebagai bahan pengayaan dalam pembahasan. Teknik mengumpulkannya dengan inventarisasi dan identifikasi dokumen hukum, kemudian peneliti melakukan kategorisasi terhadap undang-undang pidana itu. Data yang telah ada akan didiskusikan dengan prinsip-prinsip hukum (pidana) dan perspektif gender.

\section{ANALISIS DAN PEMBAHASAN}

Pengaturan Kejahatan terhadap Hak Reproduksi Perempuan dalam Kitab UndangUndang Hukum Pidana

Kitab Undang-Undang Hukum Pidana selanjutnya dalam makalah ini disebut KUHP, merupakan warisan Kolonial Belanda dengan nama Wetboek Straarecht (WvS). Keberlakuan KUHP setelah Indonesia merdeka melalui UU No. 1 Tahun 1946 tentang Peraturan Hukum Pidana. Peraturan ini selain menyatakan berlakunya Wetboek

9 Peter Mahmud Marzuki. Metode Penelitian Hukum. Jakarta: Prenada Media Group, 2013, hlm. 172. 
Straarecht $(W v S)$, juga mengubah nama Wetboek Straarecht $(W v S)$ voor Nederlands-Indie menjadi Wetboek Straarecht $(W v S)$, yang selanjutnya disebut Kitab Undang-Undang Hukum Pidana (KUHP). Sehubungan dengan warisan Kolonial, maka pemerintah melakukan penyesuaian-penyesuaian terhadap substansi KUHP agar sesuai dengan harkat dan martabat bangsa yang merdeka dan berdaulat.

Perbuatan kekerasan seksual atau kejahatan terhadap hak reproduksi perempuan tidak ada dalam KUHP, Ia hanya mengenal dalam rumusannya tentang kejahatan kesusilaan. Pengaturannya ada di Buku II, Bab XIV tentang Kejahatan terhadap Kesusilaan. Penyerangan atau pelanggaran hak reproduksi perempuan dimasukkan dalam kategori kejahatan kesusilaan, hal ini dapat dipahami, karena pertama, bahwa kesusilaan adalah aturan kesusilaan, yang sama dengan moral, yang menentukan ukuran baik dan buruk. ${ }^{10}$ Kedua, bahwa hukum termasuk hukum pidana berlandaskan moral. Hal ini sebagaimana ditegaskan oleh Hart bahwa hukum (pidana) itu memenuhi tuntutan moralitas tertentu, namun hukum pidana harus legal, sesuai dengan asas yang mendasari hukum pidana itu sendiri. 11

Pasal-pasal KUHP dalam Buku II, Bab XIV yang mengatur masalah kejahatan terhadap kesusilaan, yang bisa dikategorikan sebagai pelanggaran atau penyerahan terhadap hak reproduksi perempuan adalah:

1. Pasal 284, mengatur masalah zina antara seorang laki dengan seorang perempuan, yang salah satunya telah bersuami atau beristri. Selain itu pasal ini mengatur pula seorang laki-laki yang turut serta melakukan perbuatan zina.

2. Pasal 285, mengatur masalah perkosaan. Pasal ini menyebutkan bahwa suatu perbuatan itu disebut sebagai perkosaan, apabila perbuatan persetubuhan dilakukan di luar perkawinan dan dengan kekerasan atau ancaman kekerasan.

3. Pasal 286, mengatur persetubuhan di luar perkawinan, tetapi perempuan dalam keadaan pingsan atau tidak berdaya.

4. Pasal 287, persetubuhan di luar perkawinan dengan perempuan yang belum berusia lima belas tahun.

5. Pasal 288 merupakan lawan dari Pasal 287, karena dalam pasal ini persetubuhan yang dilakukan dalam perkawinan tetapi perempuan belum

10 Bernard Arief Sidharta. Ilmu Hukum Indonesia: Upaya Pengembangan Ilmu Hukum yang Sistematik yang Responsif Terhdap Perubahan Masyarakat. Yogyakarta: Genta Publishing, 2013, hlm. 6.

11 Hamish Stewart, "Legality and Morality in H.L.A. Hart's Theory of Criminal Law." SMU Law Review, Volume 52 Issue 1, 1999, hlm. 121-128. 
cukup umur. Ayat selanjutnya dari pasal ini mengatur pula tentang pemberatan sanksi pidana terhadap pelaku, jika perbuatannya itu mengakibatkan luka berat atau mati.

6. Pasal 289 mengatur masalah perbuatan cabul, yang perbuatan cabul dilakukan dengan kekerasan atau ancaman kekerasan.

7. Pasal 290 dan Pasal 294 ayat (1) merupakan pasal khusus tentang perbuatan cabul, kekhususan dilihat dari aspek korban yaitu perbuatan cabul dilakukan terhadap (1) seseorang yang tidak berdaya atau pingsan; (2) anak tiri; (3) anak angkat; atau (4) anak yang berada di bawah pengawasannya yang belum dewasa.

8. Pasal 292 mengatur orang yang sudah dewasa melakukan perbuatan cabul dengan sesama jenis kelamin

9. Pasal 294 merupakan pasal khusus pula perbuatan cabul, yang kekhususannya itu dilihat dari aspek pelaku, yaitu perbuatan cabul yang dilakukan oleh (1) pejabat terhadap bawahannya; (2) orang di bawah penjagaannya; (3) pengurus, dokter, guru, pesuruh dalam penjara, tempat pekerjaan negara, tempat pendidikan, rumah piatu, rumah sakit, rumah sakit jiwa atau lembaga sosial, yang melakukan perbuatan cabul dengan orang yang dimasukkan ke dalamnya.

10. Pasal 295 mengatur pula perbuatan cabul, tetapi dari sudut perbuatan dalam bentuk "memudahkan" melakukan perbuatan cabul. Ini menurut penulis maksudnya adalah memberikan jalan agar mudah dalam melakukan perbuatan itu. Perbuatan memudahkan itu untuk (diberikan) kepada anaknya, anak tirinya, anak angkatnya, atau anak di bawah pengawasannya yang belum dewasa, atau oleh orang yang belum dewasa yang pemeliharaannya, pendidikan atau penjagaannya diserahkan kepadanya, ataupun oleh bujangnya atau bawahannya yang belum cukup umur, dengan orang lain.

11. Pasal 295 ayat (2) dan Pasal 206 ini mengatur perbuatan cabul yang perbuatan menjadi suatu mata pencaharian. Perbedaannya untuk Pasal 295 ayat (2) peluang melakukan perbuatan cabul diberikan kepada orang yang memiliki hubungan khusus, sedangkan untuk Pasal 295 kesempatan melakukan perbuatan cabul itu diberikan kepada orang lain. 
12. Pasal 297, mengatur perdagangan orang laki \& perempuan yang belum dewasa. Selain itu Pasal 324 juga mengatur masalah perdagangan orang dengan predikat tertentu yaitu orang dalam arti budak belian

13. Pasal 299 mengatur masalah pengguguran kandungan terhadap perempuan hamil, baik itu dilakukan oleh setiap orang maupun oleh orang tertentu (tabib/dokter, bidan, atau juru obat).

Berdasarkan pasal-pasal di atas dapat disimpulkan bahwa pengaturan perbuatan penyerangan terhadap hak reproduksi perempuan yang dapat dikategorikan sebagai kejahatan dalam KUHP adalah (a) zina; (b) perkosaan; (c) cabul; (d) perdagangan orang; dan (e) pengguguran kandungan. Pengaturan yang demikian ini dalam perkembangannya belum bisa mengakomodasi perkembangan kejahatan terhadap hak reproduksi perempuan. Oleh karena itu di bawah ini penulis mencoba memaparkan masalah yang muncul:

\section{Perbuatan zina (adultery)}

Konsep zina dalam KUHP perbuatan yang dilakukan oleh orang yang salah satunya sudah bersuami atau beristri. Dengan kata alin perzinaan itu Hubungan seksual sukarela antara orang yang sudah menikah dan orang lain selain pasangannya (Voluntary sexual intercourse between a married person and someone other than the person's spouse.) $)^{12}$ Formulasi demikian ini belum mengakomodasi secara keseluruhan perbuatan terhadap pelanggaran hak reproduksi perempuan, karena rumusan hanya sebatas pada mereka yang sudah menikah.

Perbuatan zina berdasarkan nilai-nilai yang hidup dalam masyarakat merupakan perbuatan yang tidak disenangi atau dibenci. Mereka yang melakukan perbuatan tersebut akan mendapatkan sanksi dari masyarakat ('dicemooh'), apabila itu tidak segera menikah, karena itu merupakan aib.13 Bahkan di Masyarakat Bali yang mayoritas beragama Hindu dalam hukum adatnya menyebutkan pula bahwa zina, meskipun itu dilakukan oleh orang yang masih lajang, merupakan tindak pidana adat. ${ }^{14}$

Zina dalam konsep Islam lebih singkat dan simpel, yang pada dasarnya setiap hubungan seksual antara laki dan perempuan tanpa ikatan perkawinan adalah perbuatan

12 Bryan A. Garner (ed). Black Law Dictionary. ST Paul Mint: West Publishing, 2004, hlm. 160.

13 Kuswardani. Penelitian: Pandangan Masyarakat Terhadap Perbuatan Seksual (Studi Kasus di Sukoharjo). Surakarta: Fakultas Hukum UMS, 2010, hlm. 47.

14 Nyoman Serikat Putra Jaya. Relevansi Hukum Adat Dalam Pembaharuan Hukum Pidana. Disertasi, Jakarta: Pendidikan Pascasarjana Program Doktor UI, 2010, hlm. 189. 
zina. ${ }^{15}$ Islam tidak mempermasalahkan pelaku dari perbuatan itu apakah salah satunya sudah terikat oleh perkawinan atau belum, untuk itu pada hakikatnya perbuatan zina adalah hubungan seksual yang dilakukan oleh laki-laki dengan perempuan.

Berdasarkan hal di atas menurut penulis perlu dipertimbangkan perluasan konsep zina, karena dilihat dari pertama, aspek dampak (1) perbuatan zina mempunyai dampak yang luas seperti dampak terhadap anak-anak yang hanya mempunyai hubungan keperdataan terhadap ibunya, sehingga hak mewaris anak dari bapak hapus; (2) Bapak biologis dari anak sering kali tidak bertanggungjawab khususnya dalam aspek ekonomi. Kondisi demikian ini akan sangat berpengaruh pada kehidupan perempuan terutama bagi perempuan berada pada kondisi ekonomi lemah.

Kedua, dari aspek pandangan hidup bangsa dan dasar ideologi negara bahwa Bangsa Indonesia pada saat 17 Agustus 1945 telah bersepakat dengan menempatkan Ketuhanan Yang Maha Esa sebagai sila pertama, yang menjiwai keseluruhan nilai-nilai dari sila-sila yang lain yang berada di bawahnya, seperti nilai kemanusian, nilai persatuan dan nilai keadilan. Nilai-nilai ini merupakan panduan hidup dalam masyarakat yang terbingkai dalam hukum adat.

Ketiga, aspek normatif, bahwa pandangan hidup bangsa (yaitu Pancasila) dalam UU No. 12 Tahun 2011 Tentang Pembentukan Peraturan Perundang-Undangan, Pasal 2 menegaskan bahwa Pancasila merupakan sumber segala sumber hukum negara. Ini berarti segala peraturan perundangan substansinya tidak boleh bertentangan dengan Pancasila. Hal demikian ini berarti nilai-nilai ketuhanan, nilai kemanusiaan, nilai persatuan dan nilai keadilan merupakan nilai jiwa bangsa Indonesia yang tercermin dalam hukum yang hidup atau hukum adat. Hukum yang hidup/hukum adat mendapat pengakuan secara konstitusional dalam Pasal 18 B UUD Negara RI 1945 sebagai berikut:

(1) Negara mengakui dan menghormati satuan-satuan pemerintahan daerah yang bersifat khusus atau bersifat istimewa yang diatur dengan undang-undang.

(2) Negara mengakui dan menghormati kesatuan-kesatuan masyarakat hukum adat beserta hak-hak tradisionalnya sepanjang masih hidup dan sesuai dengan perkembangan masyarakat dan prinsip Negara Kesatuan Republik Indonesia, yang diatur dalam undang-undang.

Sehubungan dengan substansi pasal di atas berarti sifat hukum yang ada di Indonesia adalah pluralistis. Atau dengan kata lain adanya pluralisme hukum. Geoffrey

15 Syamsul Huda. "Zina Dalam Perspektif Hukum Islam Dan Kitab Undang Undang Hukum Pidana." Hunafa: Jurnal Studi Islamika. Volume 12 Issue 2, 2015, 377-297. 
Swenson, menyatakan bahwa pluralisme hukum itu mempunyai implikasi terhadap kebijakan negara di semua matra kehidupan, ia mengemukakan lima pendekatan yang bisa menjembatani antara aktor negara dan non negara berinteraksi dalam membuat kebijakan. Lima hal itu adalah harmonization, incorporation, subsidization, and repression. Pembuat kebijakan dapat memilih salah satu pendekatan atau pembuat kebijakan bisa mengombinasikan antara dua pendekatan itu dalam membuat kebijakan. 16

Keempat, dari sudut pandang feminis post modern, sebagaimana sudah dijelaskan di atas pada subbab pendahuluan bahwa untuk memahami "ke-liyan-an" perempuan tidak bisa dipahami hanya secara an sich tetapi harus ditransendenkan, maksudnya harus dipahami bahwa perempuan adalah makhluk ciptaan Tuhan yang berbeda dengan lakilaki, sehingga hak-hak perempuan itu berbeda dengan laki-laki. Jadi hak-hak perempuan termasuk hak reproduksinya merupakan anugerah Tuhan yang tidak bisa dijadikan alasan untuk memarginalkan perempuan atau melakukan perbuatan yang mengakibatkan kerugian (materiil maupun nir materiil) terhadap perempuan. Oleh karena itu negara mempunyai kewajiban untuk menghormati, menjaga dan melindungi terhadap hak tersebut, dengan mengatur kebebasan manusia maksudnya membatasi kebebasan manusia, untuk kebaikan dirinya sendiri dan orang lain serta mencegah bahaya. Pandangan ini disebut sebagai legal paternalism. Joel Feinber membenarkan penggunaan paksaan oleh negara untuk melindungi individu dari bahaya. Paksaan yang dimaksud oleh dia adalah hukum pidana. ${ }^{17}$ Jadi, hukum pidana merupakan alat negara untuk membatasi kebebasan individu guna untuk melindungi dirinya dan juga masyarakat dari bahaya. Hal demikian ini senada dengan pandangan Feminis liberal bahwa salah satu sarana yang bisa dipakai negara untuk menjaga dan melindungi hak reproduksi perempuan itu adalah aturan hukum, untuk tercapai kesejahteraan perempuan dalam arti luas. ${ }^{18}$

\section{Perkosaan (rape)}

Black Law Dictionary mengartikan bahwa rape adalah "unlawful sexual intercourse committed by a man with a woman not his wife through force and against her will." 19 Jadi,

16 Geoffrey Swenson, "Legal Pluralism In Theory And Practice." International Studies Review, Volume 20 Issue 3, 2018, hlm. 438-462.

17 Christophe Beal. "Can Paternalism Be "Soft"? Paternalism and Criminal Justice Paternalism and Criminal Justice System." Raisons Politiques Journal, 4 (44), 2011, hlm. 41-56.

18 Putnam Thong. Op. Cit., hlm. 17.

19 Bryan A. Garner (ed). Loc. Cit. 
perbuatan perkosaan itu harus dilakukan dengan kekerasan, atau perbuatan itu melawan kehendak perempuan. Dua hal ini menjadi unsur pokok dalam perbuatan perkosaan, tanpa adanya dua unsur itu perbuatan tidak bisa disebut sebagai perkosaan. KUHP pun merumuskan perkosaan juga demikian. Rumusan demikian ini akan melahirkan masalah bagi laki dan perempuan yang hidup bersama tanpa ikatan nikah atau istilah Jawa "kumpul kebo" atau cohabitation.

Perbuatan demikian sering terjadi di masyarakat, dan menjadi masalah, apabila yang melakukan adalah laki dan perempuan yang masih lajang. Karena hidup bersama atau "kumpul kebo" ini dilakukan oleh mereka secara sukarela tanpa paksaan atau ancaman. Perbuatan demikian ini apabila dilihat dari pandangan hidup bangsa yang selalu berorientasi pada nilai-nilai ketuhanan dan kemanusiaan, maka perbuatan ini merupakan perbuatan yang melanggar tatanan hidup di masyarakat. Pengaturan perbuatan perkosaan di negara lain seperti Malaysia, ${ }^{20}$ dan India lebih luas. ${ }^{21}$ Perbuatan perkosaan tidak hanya dilakukan dengan kekerasan atau ancaman kekerasan, yang dalam KUHP dua negara itu dirumuskan dengan kalimat "against her will" (bertentangan dengan kehendak perempuan). Namun juga perbuatan itu dilakukan dengan persetujuan perempuan (her consent), dikategorikan sebagai perkosaan juga. ${ }^{22}$

Perkembangan hukum dalam praktiknya, bahwa hubungan seksual dengan persetujuan perempuan pernah diputus oleh Pengadilan Negeri Bengkulu dalam Putusan No. 410/Pid. B./2014/PN. Bgl. ${ }^{23}$ Putusan hakim tersebut menjatuhkan pidana terhadap pelaku (MZ) berdasarkan Pasal 285 KUHP, perbuatan pelaku dikategorikan sama dengan perkosaan, akibat dari perbuatannya tersebut perempuan mengalami luka dan pendarahan. Putusan demikian membawa angin segar bagi dunia hukum dan perempuan, namun perlu dicatat bahwa sistem hukum di Indonesia adalah civil law system, sumber hukum utama adalah undang-undang. Selain itu bahwa hukum pidana nasional berdasar

20 Kuswardani. "Sexual Violence In Indonesia And Malaysia: A Comparative Study". Jurnal Media Hukum. Volume 26 Issue 1, 2019, hlm. 47-59

21 India Code: Digital Repository of All Central and State Act. The Indian Penal Code, 1860, https://indiacode.nic.in/handle/123456789/2263?view_type=search\&sam_handle=123456789/1362. diakses pada tanggal 20 September 2019.

22 Legislation Malaysia, Article 509 Penal Code Act 574, https://www.lexadin.nl/wlg/legis/nofr/oeur/ lxwemal.htm, diakses pada tanggal 18 Mei 2019. Lihat juga India Code: Digital Repository of All Central and State Act, Article 375, The Indian Penal Code, 1860, https://indiacode.nic.in/handle/123456789/ 2263?view_type=search\&sam_handle=123456789/1362, diakses pada tanggal 20 September 2019.

23 Mahkamah Agung, Putusan Pengadilan Negeri Bengkulu Nomor 410/Pid. B/2014/PN. Bgl Tahun 2015. https://putusan.mahkamahagung.go.id/putusan/1fcf25ca9d357dbabfc4037c653453a2, diakses pada tanggal 18 Mei 2019. 
pada asas legalitas, asas ini berkonsekuensi bahwa perbuatan pidana harus dirumuskan dalam undang-undang.

Perluasan rumusan perkosaan ini dari perspektif feminis (liberal dan post modern) justru memberikan perlindungan kepada perempuan dengan memfungsikan hukum pidana untuk mencapai ketertiban, keamanan dan kesejahteraan perempuan, dalam menafsirkan perempuan sebagai "liyan". Oleh karena itu perkosaan tidak hanya perbuatan seksual yang melawan kehendak perempuan atau dengan kekerasan atau ancaman kekerasan, melainkan juga perbuatan seksual yang tidak melawan kehendak perempuan seperti hidup bersama laki dan perempuan melakukan hubungan suami istri, karena saling mencintai, ini pun bisa dikategorikan sebagai perkosaan, karena bertentangan dengan nilai-nilai luhur bangsa. Selain itu perlu ada juga perkosaan yang dilakukan secara beramai-ramai atau oleh kelompok.

\section{Perbuatan cabul (Lewd Act)}

Perbuatan cabul berbeda dengan perbuatan pelecehan seksual (sexual abuses), perbuatan kedua lebih luas daripada perbuatan cabul, sehingga KUHP Nasional tidak bisa mengkover tindakan ini, apabila terjadi. Perbedaan dua perbuatan itu bahwa perbuatan cabul harus ada kontak fisik dan bahkan ada penetrasi, sedangkan pelecehan seksual tidak harus ada kontak fisik, bisa hanya dalam bentuk verbal. Pelecehan seksual ini bisa terjadi dimana saja dan yang sering kali terjadi di tempat kerja, dari 2008 sampai dengan 2014, Balai Pelayanan Kepulangan TKI Selapajang Tangerang mencatat sudah terjadi kasus pelecehan seksual sebanyak 11.343 kasus. ${ }^{24}$ Data ini meskipun sangat sederhana dan bukan data resmi yang dikeluarkan oleh Biro Pusat Statistik, tetapi data ini cukup memberikan gambaran tingginya angka pelecehan seksual di ranah publik (tempat kerja). Pelecehan seksual ini pun bisa terjadi di ranah negara, sebagaimana diungkapkan oleh KOMNAS, bahwa pelecehan seksual yang terjadi di ranah negara ada sebanyak 16 kasus. $^{25}$

24 CNN Indonesia. Menguak Data Jumlah Kekerasan Perempuan Tahun ke Tahun. CNN Indonesia, https://www.cnnindonesia.com/gaya-hidup/20181126110630-284-349231/menguak-data-jumlahkekerasan-perempuan-tahun-ke-tahun?, diakses pada tanggal 14 September 2019.

25 Komisi Nasional Anti Kekerasan terhadap Perempuan. Lembar Fakta dan Poin Kunci Catatan Tahunan Komnas Perempuan Tahun 2019. https://www.komnasperempuan.go.id/readnews-lembar-fakta-danpoin-kunci-catatan-tahunan-komnas-perempuan-tahun-2019, diakses pada tanggal 10 September 2019. 
KUHP Belanda sendiri telah mengatur perbuatan ini di Pasal 248 B KUHP Belanda. ${ }^{26}$ KUHP Malaysia tidak mengatur dalam pasal tersendiri tentang pelecehan seksual, namun jika perbuatan itu terjadi, maka biasanya menggunakan ketentuan Pasal 509.27 Pasal ini tidak langsung menunjuk pada perbuatan pelecehan seksual tetapi mengatur tentang penghinaan kepada seseorang. Rumusan lengkap pasal itu: ${ }^{28}$

Whoever, intending to insult the modesty of any person, utters any word, makes any sound or gesture, or exhibits any object, intending that such word or sound shall be heard, or that such gesture or object shall be seen by such person, or intrudes upon the privacy of such person, shall be punished with imprisonment for a term which may extend to five years or with fine or with both.

KUHP India juga mengatur masalah pelecehan seksual, setelah Pemerintah India mengamendemennya pada tahun 2013. Pengaturan masalah itu ada di Pasal 354 A tentang sexual harassment and punishment for sexual harassment sebagai berikut: 29

(1) A man committing any of the following acts-

(i) physical contact and advances involving unwelcome and explicit sexual overtures; or

(ii) a demand or request for sexual favours; or

(iii) showing pornography against the will of a woman; or

(iv) making sexually coloured remarks, shall be guilty of the offence of sexual harassment.

(2) Any man who commits the offence specified in clause (i) or clause (ii) or clause (iii) of sub-section (1) shall be punished with rigorous imprisonment for a term which may extend to three years, or with fine, or with both.

(3) Any man who commits the offence specified in clause (iv) of sub-section (1) shall be punished with imprisonment of either description for a term which may extend to one year, or with fine, or with both.

Berdasarkan pasal-pasal dua negara yang sudah dipaparkan di atas menunjukkan bahwa pelecehan seksual sebagai perbuatan pidana atau kejahatan yang dapat dijatuhi pidana, meskipun dalam rumusan pasal tersebut tidak secara eksplisit seperti pada rumusan KUHP Belanda.

26 LegislationOnline, Article 248 B, Criminal Code of the Kingdom of Netherlands (1881, amended 2012), https://www.legislationline.org/documents/section/criminal-codes/country/12/Netherlands/show, diakses pada tanggal 15 September 2019.

27 Jason Ong, Timely for Malaysia to have a Sexual Harrassment Act, Malaysia Kini, https://www.malaysiakini.com/news/440145, diakses pada tanggal 20 Juli 2019.

28 Legislation Malaysia, Article 509 Penal Code Act 574, https://www.lexadin.nl/wlg/legis/nofr/oeur/ lxwemal.htm, diakses pada tanggal 18 Mei 2019.

29 India Code: Digital Repository of All Central and State Act, Article 354, The Indian Penal Code, 1860, https://indiacode.nic.in/handle/123456789/2263?view_type=search\&sam_handle=123456789/1362, diakses pada tanggal 20 September 2019. 
Perbuatan pelecehan seksual pernah di proses di pengadilan yaitu PN Depok Jakarta, dengan menggunakan Pasal 281 KUHP. ${ }^{30}$ Namun rumusan itu dari pasal tersebut masih terlalu luas, sehingga perlu ada rumusan secara eksplisit terhadap perbuatan itu. Dengan demikian masyarakat mengetahui bahwa pelecehan seksual termasuk kejahatan yang bisa dijatuhi pidana. Selain hal itu, rumusan secara eksplisit sebagai bentuk interpretasi dari nilai-nilai yang menjadi dasar dan sumber dari segala sumber hukum negara, yaitu nilai ketuhanan, nilai kemanusiaan, dan nilai keadilan.

\section{Pengaturan Kejahatan terhadap Hak Reproduksi Perempuan di luar KUHP}

Perkembangan kejahatan menuntut adanya perkembangan hukum pidana, yang tidak cukup hanya bentuk-bentuk kejahatan sebagaimana formulasi dalam KUHP. Oleh karena itu negara melakukan upaya-upaya pembaharuan hukum pidana agar bisa memadai terhadap perbuatan-perbuatan yang dianggap sebagai kejahatan. Pendekatan yang digunakan negara untuk melakukan pembaharuan hukum pidana, terutama perkembangan kejahatan termasuk perkembangan kejahatan terhadap hak reproduksi perempuan dengan pendekatan (semi) global, dan pendekatan komplementer. ${ }^{31}$ Pendekatan (semi) global itu merupakan pendekatan yang menempuh cara dengan pengaturan khusus di luar KUHP. Contoh dari pendekatan ini dengan disahkannya undang-undang Perlindungan anak, undang-undang penghapusan kekerasan dalam rumah tangga, undang-undang tindak pidana perdagangan orang. Pendekatan komplementer merupakan pendekatan pembaharuan hukum pidana dengan cara mendayagunakan sanksi pidana untuk memperkuat sanksi administrasi. Contohnya undang-undang kesehatan. ${ }^{32}$

Pengesahan undang-undang pidana baru khususnya yang mengatur masalah kejahatan terhadap hak reproduksi perempuan (termasuk anak perempuan), tidak bisa dilepaskan dari pengesahan konvensi diskriminasi perempuan dan konvensi hak anak oleh Pemerintah Indonesia. Pengesahan dua konvensi itu dengan UU No. 7/1984 tentang Pengesahan Konvensi Mengenai Penghapusan Segala Bentuk Diskriminasi Terhadap

30 Cynthia Lova. Pelaku Pelecehan Seksual di Depok Divonis 1 Tahun Penjara. Kompas.com, https://megapolitan.kompas.com/read/2018/08/09/18234321/pelaku-pelecehan-seksual-di-depokdivonis-1-tahun-penjara, diakses pada tanggal 10 September 2019.

31 Muladi \& Diah Sulistyani R. Kompleksitas Perkembangan Tindak Pidana dan Kebijakan Kriminal, Bandung: Alumni. 2016, hlm. 27.

32 Ibid, hlm. 28. 
Wanita (Convention on the elimination of All Forms of Discrimination agains Women), sedangkan untuk konvensi hak anak dengan Keputusan Presiden No. 36/1990 tentang Pengesahan Convention On The Rights of The Child (Konvensi Tentang Hak-Hak Anak). Perbuatan-perbuatan yang dikategorikan sebagai kejahatan yang dirumuskan di luar KUHP disebut sebagai tindak pidana khusus. Adapun kejahatan-kejahatan itu antara lain meliputi kejahatan yang terjadi dalam lingkup rumah tangga, kejahatan terhadap anak baik yang terjadi di lingkup rumah tangga maupun di lingkup komunitas. Kejahatan tentang perdagangan perempuan dan anak, yang pengaturannya bersifat umum yaitu dengan sebutan undang-undang tindak pidana perdagangan orang. Oleh karena itu di bawah ini dipaparkan undang-undang tersebut yang terkait dengan masalah kejahatan terhadap hak reproduksi perempuan, sebagai berikut:

\section{UU No. 23/2002 tentang Perlindungan Anak}

Undang Perlindungan Anak merupakan sebuah konsekuensi negara meratifikasi Konvensi Hak Anak. Keberlakuan undang-undang ini mengesampingkan ketentuan-ketentuan KUHP yang terkait dengan kejahatan terhadap anak seperti Pasal 287 dan Pasal 294 KUHP, karena undang-undang pidana ini (Perlindungan Anak) merupakan undangundang yang bersifat khusus dan KUHP merupakan undang-undang pidana yang sifatnya umum (asas lex specialis derogat legi generali).

Pengaturan masalah anak sudah ada sebelum negara meratifikasi hak anak, yaitu UU No. 4/1979 tentang Kesejahteraan Anak, substansi undang-undang ini sudah mengatur pula masalah hak anak secara administratif saja. Selain itu substansi pengaturannya belum lengkap dan terperinci, karena (1) konsep kesejahteraan anak hanya sebatas terpenuhinya kebutuhan pokok, untuk pertumbuhan dan perkembangan anak; (2) Hak anak dalam undang-undang ini hanya berorientasi pada hak kesejahteraan untuk memperoleh perawatan, asuhan dan bimbingan berdasarkan kasih sayang baik dari orang tua, dan berhak atas pelayanan kesehatan dan pendidikan; (3) Hak perlindungan terhadap anak dalam undang-undang hanya pada perlindungan terhadap lingkungan hidup yang dapat membahayakan (yaitu mengancam jiwa manusia) atau menghambat pertumbuhan dan perkembangan dengan wajar, yang disebabkan karena alam atau perbuatan manusia. Namun demikian substansi berikutnya tidak menyebutkan khususnya tentang perbuatan manusia yang bagaimana yang dimaksud undang-undang yang membahayakan anak, dan apabila itu terjadi dalam kehidupan, maka orang tua atau wali atau negara harus bagaimana tidak ada pengaturannya. 
UU No. 23/2002 tentang Perlindungan Anak ini substansinya lebih memadai baik aspek administrasi, perdata dan pidana, sehingga bisa memberikan jawaban terhadap pertanyaan yang menjadi masalah dalam makalah ini. Meskipun ada beberapa kelemahan, yang kemudian negara melakukan perubahan terhadap undang-undang itu. Negara sudah melakukan perubahan terhadap undang-undang ini sebanyak dua kali.

Perubahan pertama dilakukan oleh negara dengan UU No. 35/2014 tentang Perubahan atas UU No. 23/2002 tentang Perlindungan Anak. Perubahannya meliputi antara lain:

Tabel. 2 Angka kekerasan seksual yang tercatat tahun 2017 dan 2018

\begin{tabular}{|c|c|c|}
\hline No. & Aspek & UU No. $23 / 2002$ \\
\hline 1 & Perubahan Istilah & Anak menyandang cacat \\
\hline 2 & $\begin{array}{l}\text { Kewajiban } \\
\text { Pemenuhan } \\
\text { terhadap hak anak }\end{array}$ & $\begin{array}{l}\text { Orang tua, keluarga, masyarakat, } \\
\text { pemerintah, dan negara }\end{array}$ \\
\hline 3 & $\begin{array}{l}\text { Konsep kekerasan } \\
\text { terhadap anak }\end{array}$ & Belum ada \\
\hline 4 & $\begin{array}{l}\text { Pertegas } \\
\text { perlindungan anak } \\
\text { disatuan pendidikan }\end{array}$ & Belum ada \\
\hline 5 & $\begin{array}{l}\text { Perlindungan dari } \\
\text { pengaruh pornografi }\end{array}$ & Belum ada \\
\hline 6 & $\begin{array}{l}\text { Perlindungan } \\
\text { Khusus terhadap } \\
\text { anak }\end{array}$ & $\begin{array}{l}\text { Diberikan anak dalam situasi darurat, } \\
\text { anak yang berhadapan dengan hukum, } \\
\text { anak dari kelompok minoritas \& } \\
\text { terisolasi, anak tereksploitasi secara } \\
\text { ekonomi dan/atau seksual, anak yang } \\
\text { diperdagangkan, anak yang menjadi } \\
\text { korban penyalahgunaan narkotika, } \\
\text { alkohol, psikotropika, dan zat adiktif } \\
\text { lainnya (napza), anak korban } \\
\text { penculikan, penjualan dan } \\
\text { perdagangan, anak korban kekerasan } \\
\text { baik fisik dan/atau mental, anak yang } \\
\text { menyandang cacat, dan anak korban } \\
\text { perlakuan salah dan penelantaran. }\end{array}$ \\
\hline 7 & $\begin{array}{l}\text { Pengaturan } \\
\text { Pendanaan }\end{array}$ & $\begin{array}{l}\text { Tidak diatur secara tegas, hanya } \\
\text { dirumuskan bahwa Negara dan } \\
\text { pemerintah berkewajiban dan } \\
\text { bertanggung jawab memberikan } \\
\text { dukungan sarana dan prasarana dalam } \\
\text { penyelenggaraan perlindungan anak. }\end{array}$ \\
\hline
\end{tabular}

Anak Penyandang Disabilitas

Orang tua, keluarga, negara, pemerintah \& pemerintah daerah

Kekerasan adalah setiap perbuatan terhadap Anak yang berakibat timbulnya kesengsaraan atau penderitaan secara fisik, psikis, seksual, dan/atau penelantaran, termasuk ancaman untuk melakukan perbuatan, pemaksaan, atau perampasan kemerdekaan secara melawan hukum.

Ada diatur dalam Pasal 9 ayat (1 a).

Penyebutan secara tegas tentang tindakan yang harus dihindari: Kekerasan fisik, psikis, kejahatan seksual, dan kejahatan lainnya yang dilakukan oleh pendidik, tenaga kependidikan, sesama peserta didik, dan/atau pihak lain.

Perumusan ada dalam Pasal 67 A.

Penambahan perlindungan terhadap anak korban pornografi, Anak HIV/AIDS, jaringan terorisme, anak yang menjadi korban stigmatisasi dari pelabelan terkait dengan kondisi orang tuanya.

Pengaturan secara tegas di rumuskan dalam Pasal 71 E, bahwa dana untuk penyelenggaraan perlindungan dari APBN, APBD dan sumber lain yang sah \& tidak mengikat. 
8 Perbuatan/kekerasa n pidana terhadap anak

9 Perumusan sanksi pidana
Langsung merumuskan perbuatan berikut sanksi pidana dalam Pasal 77 s/d Pasal 90.
Perumusan perbuatan-perbuatan yang dilarang yang lebih diperluas. Kemudian terhadap larangan itu dirumuskan perbuatan pidananya berikut sanksi pidananya dalam Pasal 77 s/d Pasal 90.

Sama, tetapi ada penambahan terhadap perbuatan aborsi terhadap anak dalam kandungan, sanksi pidana bersifat kumulatif

Perubahan kedua UU Perlindungan Anak ini dengan Peraturan Pemerintah Pengganti Undang-Undang (PERPU) No. 1/2016 tentang Perubahan Kedua atas UU No. 23/2002 tentang Perlindungan Anak. PERPU ini kemudian disahkan dengan UU No. 17/2016 tentang Penetapan Peraturan Pemerintah Pengganti Undang-Undang No. 1/2016 tentang Perubahan Kedua atas UU No. 23/2002 tentang Perlindungan Anak. Perubahan kedua ini adalah penambahan sanksi pidana terutama terhadap perbuatan kekerasan seksual terhadap anak. Bentuk penambahan sanksi pidana itu (1) berupa tindakan dalam bentuk kebiri kimia dan pemasangan alat pendeteksi elektronik dengan disertai rehabilitasi; dan (2) berupa sanksi tambahan dalam bentuk pengumuman identitas pelaku, kecuali jika pelaku anak maka ini tidak bisa dikenakan.

Respons terhadap perbuatan pidana, kekerasan seksual terhadap anak dalam bentuk sanksi pengebirian kimia memang berat. Hal ini dapat dipahami dari dua aspek yaitu aspek non hukum dan aspek hukum. Aspek non hukum yaitu (1) nilai-nilai ketuhanan merupakan spirit bangsa dalam tindak perilaku, dan Tuhan sangat mengutuk tindakan seksual yang amoral; (2) Korban, korban adalah anak yang merupakan aset bangsa yang menentukan kelangsungan hidup bangsa, sehingga perlu pendidikan dan suriteladan dari orang tua dan masyarakat agar bisa menjadi penerus, pejuang yang tangguh. Aspek hukum (pidana) bahwa (1) Tujuan hukum pidana sebagai alat untuk mencegah dan menakuti-nakuti masyarakat agar tidak melakukan kejahatan. Selain itu tujuan hukum pidana adalah memperbaiki si pelaku; (2) Sifat hukum pidana adalah ultimum remidium artinya hukum pidana adalah obat terakhir maksudnya hukum pidana bisa diterapkan apabila sanksi dari hukum yang lain sudah tidak berdaya guna lagi.

Undang-undang ini juga melarang pengguguran kandungan (abortion), kecuali dengan alasan tertentu, karena menggugurkan kandungan itu termasuk perampasan hak asasi manusia anak. Jaminan hukum terhadap hak anak dalam Pasal 28 B ayat (2) UUD Negara RI 1945, bahwa " setiap anak berhak atas kelangsungan hidup, tumbuh, dan 
berkembang serta berhak atas perlindungan dari kekerasan dan diskriminasi." Adapun alasan-alasan dapat melakukan aborsi ada dalam Pasal 75 ayat (2) UU No. 36/2009 tentang Kesehatan yaitu karena (a) indikasi kedaruratan medis yang dideteksi sejak usia dini; (b) kehamilan akibat perkosaan yang dapat menyebabkan trauma psikologis bagi korban perkosaan.

\section{UU No. 23/2004 tentang Penghapusan Kekerasan Dalam Rumah Tangga (UU PKDRT)}

Kekhususan Undang-undang ini, pertama, mengenai istilah kejahatan atau tindak pidana. UU ini tidak mengenal istilah kejahatan yang ada dalam undang-undang ini adalah istilah kekerasan. Istilah ini (kekerasan) dilihat dari perspektif KUHP merupakan sebuah istilah yang untuk menunjukkan bahwa perbuatan itu merupakan sebuah kejahatan yang serius, karena kekerasan itu adalah perbuatan yang menggunakan tenaga kekuatan yang tidak kecil dan tidak syah, sehingga orang menjadi tidak berdaya. 33 Substansi dari undangundang ini menjelaskan langsung pada konsep kekerasan rumah tangga dalam Pasal 1 angka 1 sebagai berikut:

"Kekerasan dalam Rumah Tangga adalah setiap perbuatan terhadap seseorang terutama perempuan, yang berakibat timbulnya kesengsaraan atau penderitaan secara fisik, seksual, psikologis, dan/atau penelantaran rumah tangga termasuk ancaman untuk melakukan perbuatan, pemaksaan, atau perampasan kemerdekaan secara melawan hukum dalam lingkup rumah tangga."

Berdasarkan rumusan pasal di atas kejahatan dalam rumah tangga merupakan kejahatan yang cukup serius yang ditunjukkan dengan rumusan kalimat "ancaman untuk melakukan perbuatan, pemaksaan, atau perampasan kemerdekaan secara melawan hukum."

Kedua, mengenai lingkup berlakunya bahwa undang-undang ini hanya berlaku untuk orang-orang yang tertentu, sebagaimana disebutkan dalam Pasal 2 UU ini, yaitu (a) suami, istri dan anak; (b) orang-orang yang mempunyai hubungan keluarga dengan suami, istri dan anak karena hubungan darah, perkawinan, persusuan, pengasuhan dan perwalian, yang menetap dalam rumah tangga; (c) orang yang bekerja membantu rumah tangga dan menetap dalam rumah tangga tersebut. Jadi ada persyaratan tertentu bagi orang-orang yang bukan suami, istri atau anak, yaitu harus menetap tinggal dalam rumah tangga tersebut.

33 R. Soesilo. Kitab Undang-Undang Hukum Pidana (KUHP) sera Komentar Komentarnya Lengkap Pasal Demi Pasal, Bogor: Politea, 2013, hlm. 98. 
Kekhususan yang lain undang-undang ini bahwa undang-undang ini utamanya untuk melindungi perempuan (istri), yang dapat diketahui dari rumusan konsep KDRT), mengingat perempuan (istri) rentan terhadap tindak kekerasan dari suami yang dalam Catatan Tahunan KOMNAS Perempuan dua tahun terakhir masih menduduki peringkat pertama. ${ }^{34}$

Undang-undang ini memformulasi kejahatan terhadap hak reproduksi perempuan dengan istilah kekerasan seksual. Kekerasan seksual yang terjadi antara suami-istri lazim disebut dengan marital rape (perkosaan dalam perkawinan), yaitu a husband's sexual intercourse with his wife by force or without her consent. ${ }^{35}$ Pasal 5 huruf c UU Penghapusan KDRT menyebutkan konsep kekerasan seksual yaitu (a) pemaksaan hubungan seksual yang dilakukan terhadap orang yang menetap dalam lingkup rumah tangga tersebut; (b) pemaksaan hubungan seksual terhadap salah seorang dalam lingkup rumah tangganya dengan orang lain untuk tujuan komersial dan/atau tujuan tertentu. Perumusan kejahatan terhadap reproduksi perempuan dalam undang-undang ini atau yang disebut dengan marital rape, "pemaksaan” merupakan unsur utama. Islam juga mengajarkan bagaimana suami istri itu berhubungan dalam kehidupan sehari-hari, termasuk dalam hubungan seksual, seperti disebutkan dalam Quran Surat An Nisaa (surat ke 4) ayat 19 bahwa suami diperintah menggauli istri dengan cara yang makruf (baik). Asas mu'asyarah bil ma'rufini harus menjadi dasar di dalam pergaulan dengan istri baik dalam perkataan maupun perbuatan sehari-hari termasuk perbuatan dalam melakukan hubungan seksual. (Fahmi, 2015) Jadi pemaksaan hubungan seksual oleh suami kepada istrinya merupakan perbuatan yang tidak diperbolehkan dalam ajaran Islam. Oleh karena itu undang-undang ini tidaklah bertentangan dengan nilai-nilai ketuhanan (Islam), karena undang-undang ini hanya merumuskan secara konkret tentang hubungan seksual yang tidak makruf atau tidak baik yang berefek pada kekerasan seksual. Hal ini menurut Kuntowijoyo merupakan objektifikasi terhadap nilai-nilai Islam. ${ }^{36}$

\footnotetext{
34 Komisi Nasional Anti Kekerasan terhadap Perempuan. Lembar Fakta dan Poin Kunci Catatan Tahunan Komnas Perempuan Tahun 2019. https://www.komnasperempuan.go.id/readnews-lembar-fakta-danpoin-kunci-catatan-tahunan-komnas-perempuan-tahun-2019, diakses pada tanggal 10 September 2019.

35 Bryan A. Garner (ed). Op. cit., hlm. 393.

36 Kuntowijoyo, Budaya dan Masyarakat. Yogyakarta: Tiara Wacana, 2006, hlm. 63.
} 
UU No. 21/2017 tentang Pemberantasan Tindak Perdagangan Orang (UU Pemberantasan TPPO)

Undang-undang Pemberantasan TPPO menghapuskan Pasal 297 dan 324 KUHP yang dinyatakan secara tegas dalam Bab IX: Ketentuan Penutup, Pasal 65. Ini berbeda dengan UU No. 23/2002 tentang Perlindungan Anak, yang dalam undang-undang ini di Bab XIII: Ketentuan Peralihan, Pasal 91 menyatakan bahwa semua peraturan perundang-undangan yang berkaitan dengan perlindungan anak yang sudah ada dinyatakan tetap berlaku sepanjang tidak bertentangan dengan undang-undang ini. Oleh karena itu terhadap undang-undang Perlindungan anak berlaku asas lex spesialis derogat legi generalis, sedangkan untuk undang-undang yang kedua berlaku asas Lex post teriori derogat legi priori.

Undang-undang ini bersifat umum tidak hanya untuk perempuan dan/atau anak, karena melihat dari titel undang-undang itu dengan menggunakan istilah "tindak pidana perdagangan orang", Namun substansi undang-undang ini tidak lain adalah memberikan perlindungan kepada perempuan dan/atau anak agar tidak menjadi korban perdagangan orang. Hal ini dapat diketahui dari (1) Bagian pertimbangan, secara jelas menyebutkan bahwa "perdagangan orang khususnya perempuan dan anak...." (2) Bagian mengingat menyebutkan bahwa dasar dari pembentukan undang-undang ini adalah UU No.7/1984 tentang Pengesahan Penghapusan Segala Bentuk Diskriminasi terhadap Perempuan (Convention on The Elimination of All Forms of Discrimination againt Women), di samping itu juga UU No. 23/2002 tentang Perlindungan Anak. (3) Bagian Penjelasan Umum, dengan tegas menyebutkan bahwa "bukti empiris, perempuan dan anak adalah kelompok yang paling banyak menjadi korban tindak pidana perdagangan orang."

Undang-undang ini berhubungan pula dengan masalah hak reproduksi perempuan, meskipun dalam rumusan tindak pidana perdagangan orang tidak menyebutkan secara lugas masalah kata hak reproduksi perempuan (seksual), atau reproduksi perempuan, kecuali Pasal 7 menyebutkan secara jelas "fungsi reproduksi". Namun demikian undangundang sebagai undang-undang yang juga merumuskan perbuatan yang merupakan kejahatan terhadap hak reproduksi perempuan, yang dapat diketahui dengan rumusan kata "mengeksploitasi" atau "dieksploitasi." Dua kata itu berasal dari kata dasar "eksploitasi", yang dalam undang-undang mempunyai arti luas, sebagaimana dirumuskan dalam Pasal 1 angka 7 yaitu: 
Eksploitasi adalah tindakan dengan atau tanpa persetujuan korban yang meliputi tetapi tidak terbatas pada pelacuran, kerja atau pelayanan paksa, perbudakan atau praktik serupa perbudakan, penindasan, pemerasan, pemanfaatan fisik, seksual, organ reproduksi, atau secara melawan hukum memindahkan atau mentransplantasi organ dan/atau jaringan tubuh atau memanfaatkan tenaga atau kemampuan seseorang oleh pihak lain untuk mendapatkan keuntungan baik materiil maupun immateriil.

Jadi dalam perbuatan tindak pidana perdagangan orang ini persetujuan korban bukan merupakan salah satu alasan untuk menghapuskan pidana. Selain itu dalam bagian Penjelasan Pasal 2 ayat (1) juga disebutkan bahwa tindak pidana perdagangan orang itu merupakan delik formil, sehingga dengan terpenuhi unsur-unsur perbuatan yang telah dirumuskan dalam undang-undang ini, tanpa harus menimbulkan akibat, perbuatan tersebut sudah dapat dijatuhi pidana.

\section{KESIMPULAN}

Hukum pidana (substantif) positif Indonesia telah mengatur pelanggaran atau penyerangan terhadap hak reproduksi perempuan. Pengaturan ini ada dalam KUHP maupun di Luar KUHP. KUHP mengatur perbuatan itu ada dalam rumusan kejahatan terhadap kesusilaan yang meliputi zina, perkosaan, dan cabul. Pengaturan di luar KUHP meliputi UU No.23/2004 tentang Penghapusan Kekerasan Dalam Rumah Tangga; UU No. 23/2002 tentang perlindungan anak dengan perubahannya; UU No. 21/2007 tentang Tindak Pidana Perdagangan Orang, yang menghapuskan ketentuan KUHP tentang perdagangan manusia.

Namun demikian, kelemahan atau kekurangan dalam mengatur kejahatan terhadap hak reproduksi perempuan masih juga ada, terutama yang ada dalam KUHP. Kelemahan itu pertama, pengaturan masalah perbuatan zina yang seharusnya rumusannya. Kedua, memperluas atau menambahkan rumusan perkosaan tidak hanya dengan kekerasan atau ancaman kekerasan tetapi dengan kesepakatan, karena ada janjijanji tertentu pun harus bisa dikategorikan sebagai perkosaan. Ketiga, penegasan pengaturan tentang pelecehan seksual, terutama di tempat kerja. Beberapa hal Ini perlu mendapatkan perhatian pemerintah untuk melakukan reformulasi terhadap hukum pidana nasional. 


\section{Daftar Pustaka}

\section{Buku}

Arief, Barda Nawawi, Perkembangan Sistem Pemidanaan di Indonesia. Semarang: Program Pascasarjana UNDIP, 2015.

Garner, Bryan A. (ed). Black Law Dictionary. ST Paul Mint: West Publishing, 2004.

Harriej, Eddy 0, Prinsip-prinsip Hukum Pidana, Yogyakarta: Cahya Atma Pustaka, 2016.

Kelsen, Hans, Teori Umum tentang Hukum dan Negara, Penerjemah Raisul Muttaqien, Bandung: Nusa Media, 2011.

Kuntowijoyo, Budaya dan Masyarakat. Yogyakarta: Tiara Wacana, 2006.

Kuswardani. Penelitian: Pandangan Masyarakat Terhadap Perbuatan Seksual (Studi Kasus di Sukoharjo). Surakarta: Fakultas Hukum UMS, 2010.

Marzuki, Peter Mahmud, Metode Penelitian Hukum. Jakarta: Prenada Media Group, 2013.

Muladi \& Diah Sulistyani R. Kompleksitas Perkembangan Tindak Pidana dan Kebijakan Kriminal, Bandung: Alumni. 2016.

Sidharta, Bernard Arief, Ilmu Hukum Indonesia: Upaya Pengembangan Ilmu Hukum yang Sistematik yang Responsif Terhdap Perubahan Masyarakat. Yogyakarta: Genta Publishing, 2013.

SJ, Tom Jacob, Faham Allah Dalam Filsafat Agama-Agama dan Teologi. Yogyakarta: Kanisus, 2002.

Soesilo, R., Kitab Undang-Undang Hukum Pidana (KUHP) sera Komentar Komentarnya Lengkap Pasal Demi Pasal, Bogor: Politea, 2013.

Thong, Rosemarie Putnam, Pengantar Paling Komprehensif kepada Arus Utama Pemikiran Feminis. Yogyakarta: Jalasutra, 2004.

\section{Jurnal dan Disertasi}

Beal, Christophe, "Can Paternalism Be "Soft"? Paternalism and Criminal Justice Paternalism and Criminal Justice System." Raisons Politiques Journal, 4 (44), 2011.

Huda, Syamsul, “Zina Dalam Perspektif Hukum Islam Dan Kitab Undang Undang Hukum Pidana." Hunafa: Jurnal Studi Islamika. Volume 12 Issue 2, 2015.

Jaya, Nyoman Serikat Putra, Relevansi Hukum Adat Dalam Pembaharuan Hukum Pidana. Disertasi, Jakarta: Pendidikan Pascasarjana Program Doktor UI, 2010.

Kuswardani, "Sexual Violence In Indonesia And Malaysia: A Comparative Study". Jurnal Media Hukum. Volume 26 Issue 1, 2019. 
Stewart, Hamish, "Legality and Morality in H.L.A. Hart's Theory of Criminal Law." SMU Law Review, Volume 52 Issue 1, 1999.

Swenson, Geoffrey, “Legal Pluralism In Theory And Practice.” International Studies Review, Volume 20 Issue 3, 2018.

Taylor, Lauren R., Nicole Gaskin-Laniyan. "Sexual Assault in Abusive Relationships". NIJ Journal, Issue No. 256, 2007.

\section{Situs web}

CNN Indonesia. Menguak Data Jumlah Kekerasan Perempuan Tahun ke Tahun. CNN Indonesia, https://www.cnnindonesia.com/gaya-hidup/20181126110630-284349231/menguak-data-jumlah-kekerasan-perempuan-tahun-ke-tahun?, diakses pada tanggal 14 September 2019.

India Code: Digital Repository of All Central and State Act. The Indian Penal Code, 1860, https://indiacode.nic.in/handle/123456789/2263?view_type=search\&sam_handl e=123456789/1362. diakses pada tanggal 20 September 2019.

IPPF Organisation. Hak-Hak Seksual: Deklarasi IPPF. International Planned Parenthood Federation, 2006, https://www.ippf.org/sites/default/files/ippf_sexual_rights_ declaration_bahasa.pdf, diakses pada tanggal 19 September 2019.

Komisi Nasional Anti Kekerasan terhadap Perempuan, CATAHU: Catatan Tahunan 2018, https://www.komnasperempuan.go.id/file/pdf_file/2018/SIARAN\%20PERS\%20 2018/Lembar\%20Fakta\%20Catahu\%207\%20Maret\%202018.pdf, diakses pada tanggal 17 Juli 2019.

Komisi Nasional Anti Kekerasan terhadap Perempuan, CATAHU: Catatan Tahunan 2019, https://www.komnasperempuan.go.id/file/Catatan\%20Tahunan\%20Kekerasan \%20Terhadap\%20Perempuan\%202019.pdf, diakses pada tanggal 17 Juli 2019.

Komisi Nasional Anti Kekerasan terhadap Perempuan. Lembar Fakta dan Poin Kunci Catatan Tahunan Komnas Perempuan 2019. https://www.komnasperempuan.go.id/readnews-lembar-fakta-dan-poin-kuncicatatan-tahunan-komnas-perempuan-tahun-2019, diakses pada tanggal 10 September 2019.

Legislation Malaysia, Penal Code Act 574, https://www.lexadin.nl/wlg/legis/nofr/oeur/ lxwemal.htm, diakses pada tanggal 18 Mei 2019. 
LegislationOnline, Article 248 B, Criminal Code of the Kingdom of Netherlands (1881, amended 2012), https://www.legislationline.org/documents/section/criminalcodes/country/12/Netherlands/show, diakses pada tanggal 15 September 2019.

Lova, Cynthia, Pelaku Pelecehan Seksual di Depok Divonis 1 Tahun Penjara. Kompas.com, https://megapolitan.kompas.com/read/2018/08/09/18234321/pelakupelecehan-seksual-di-depok-divonis-1-tahun-penjara, diakses pada tanggal 10 September 2019.

Mahkamah Agung, Putusan Pengadilan Negeri Bengkulu Nomor 410/Pid. B/2014/PN. Bgl Tahun 2015. https://putusan.mahkamahagung.go.id/putusan/1fcf25ca9d357dba bfc4037c653453a2, diakses pada tanggal 18 Mei 2019.

Ong, Jason, Timely for Malaysia to have a Sexual Harrassment Act, Malaysia Kini, https://www.malaysiakini.com/news/440145, diakses pada tanggal 20 Juli 2019. 